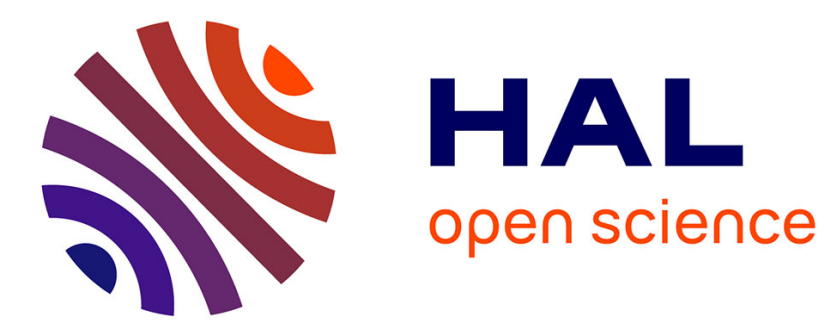

\title{
Falciform ligament wrap during laparoscopic pancreatoduodenectomy
}

F. Werey, F. Browet, F. Mauvais

\section{To cite this version:}

F. Werey, F. Browet, F. Mauvais. Falciform ligament wrap during laparoscopic pancreatoduodenectomy. Journal of Visceral Surgery, 2019, 156, pp.50 - 54. 10.1016/j.jviscsurg.2018.11.004 . hal03486524

\section{HAL Id: hal-03486524 \\ https://hal.science/hal-03486524}

Submitted on 21 Dec 2021

HAL is a multi-disciplinary open access archive for the deposit and dissemination of scientific research documents, whether they are published or not. The documents may come from teaching and research institutions in France or abroad, or from public or private research centers.
L'archive ouverte pluridisciplinaire HAL, est destinée au dépôt et à la diffusion de documents scientifiques de niveau recherche, publiés ou non, émanant des établissements d'enseignement et de recherche français ou étrangers, des laboratoires publics ou privés.

\section{다)(1) $(5$}

Distributed under a Creative Commons Attribution - NonCommercial| 4.0 International 
Lambeau de ligament falciforme lors de la duodénopancréatectomie céphalique par laparotomie

Titre court : Lambeau de ligament falciforme

$\underline{\text { Auteurs : F. Werey M.D }}{ }^{1,2}$; F.Browet M.D ${ }^{1,2,3} ;$ F.Mauvais M.D ${ }^{1,2,3}$

1- Service de chirurgie viscérale et digestive, centre hospitalier de Beauvais, avenue Léon Blum, BP 40319 Beauvais Cedex, France

2- Service de chirurgie digestive, centre hospitalier universitaire Amiens, avenue René Laënnec, 80054 Amiens Cedex 1, France

3- Unité de recherche clinique SPCC (soins patients chirurgicaux complexes), université de Picardie Jules Vernes, avenue René Laënnec, 80054 Amiens Cedex 1

\section{$\underline{\text { Auteur correspondant : }}$}

Docteur Browet François

Service de chirurgie viscérale et digestive,

centre hospitalier de Beauvais,

avenue Léon Blum,

BP 40319 Beauvais Cedex, France

Telephone : 0344112242

Mail : f.browet@ch-beauvais.fr 
Falciform ligament wrap during laparoscopic pancreatoduodenectomy

Short (running) title: Falciform ligament wrap

Introduction:

The falciform ligament wrap has been proposed to decrease the risk of bleeding complications after pancreatoduodenectomy (PD) [1], and a controlled randomized trial on its use is currently underway [2]. This technique has also been described to decrease the risk of pancreatic fistula [3,4]. It can also be used as an alternative to omentoplasty in case of perforated gastroduodenal peptic ulcer [5], to fill the space left after hepatic resection or to close large hiatal hernia defects [6]. Lastly, it can be used for bile duct injury repair [7].

Figure 1. The flap is simple and quick to create and raise; it is well vascularized and can be used anywhere in the right upper quadrant of the abdomen. It is composed of a broad tissue flap (falciform ligament and preperitoneal fatty tissue), which is vascularized by the round ligament [8]. After complicated PD, it can be used to cover the exposed vessels to limit the risk of pseudo-aneurysm in case of pancreatic fistula.

It is not necessary to change patient position on the operating table to create it. The flap can be raised whatever the approach: midline, 
subcostal or laparoscopy. However, the decision to do so should be made early, as the first step of the operation. It is therefore important to foresee its need, protect it once it is ready, and use it at the end of the operation.

Figure 2. Via a midline incision, the linea alba is opened from the xiphoid to the umbilicus. The preperitoneal fatty tissues are retracted cephalad. At the junction between the fatty tissues and the fascia, electric cautery dissection is directed laterally until the fatty tissues disappear (approximately $5 \mathrm{~cm}$ on each side), the peritoneum is divided from the umbilical fatty tissues to the xiphoid.

Figure 3. This step is performed in the same manner on the left as on the right. At the level of the umbilicus, peritoneum and fatty tissues are ligated with absorbable sutures and then divided. Beyond the xiphoid, the fatty tissues have to be divided to reach the falciform ligament close to the diaphragm.

Figure 4. The liver is pushed posterior to put the falciform ligament under tension before dividing it with electric cautery near the diaphragm from anterior to posterior.

Figure 5. The falciform ligament is thus divided near the liver. It is however important not to cut the falciform ligament too close to 
segment IVb because there are several small feeding vessels that, if interrupted, can lead to partial ischemia of the flap.

Figure 6. To best preserve the flap, the round ligament must not be twisted and the flap must not be compressed. The flap is placed in a humid and warm gauze. It should be placed in front of hepatic segment IVb in order not to hinder any later part of the procedure and avoid any biliary contamination.

Figure 7. The flap is fixed in position before performing the pancreatic anastomosis, after checking that it is well vascularized and that the pancreatic stump and the common hepatic duct are adequately mobilized $(2 \mathrm{~cm}$ for the pancreatic stump and $1 \mathrm{~cm}$ for the common hepatic duct). Whatever the type of anastomosis, the palette of the flap is placed horizontally to cover the exposed vessels. It should be first fixed to the superior then to the inferior border of the pancreas, approximately $2 \mathrm{~cm}$ from the pancreatic division. Next, the flap is anchored (interrupted absorbable sutures) in a counter-clockwise direction to cover the area of lymph node dissection (superior border of the pancreas to the superior border of the hepatic pedicle, the common hepatic duct anterior to the flap, then Gerota's fascia and finally from the inferior mesenteric vein to the inferior border of the pancreas). 
Figure 8. The flap protects the vessels and facilitates the evacuation of pancreatic fluids by realizing a sort of "amylase toboggan".

Figure 9. Last, the operation is pursued as usual to perform the pancreatico-jejunostomy, hepatico-jejunostomy, gastro-jejunostomy and drain insertion.

\section{References:}

1. Ray S, Sanyal S, Ghatak S, Sonar PK, Das S, Khamrui S, Chattopadhyay $G$. Falciform ligament flap for the protection of the gastroduodenal artery stump after pancreaticoduodenectomy: A single center experience. J Vis Surg 2016;153: 9-13.

2. Müssle B, Zühlke L, Wierick $A$, Sturm D, Grählert X, Distler $M$, Rahbari NN, Weitz J, Welsch T. Pancreatoduodenectomy with or without prophylactic falciform ligament wrap around the gastroduodenal artery stump for prevention of pancreatectomy hemorrhage. Trials. 2018;19: 222.

3. Walters DM, Stokes JB, Adams RB, Bauer TW. Use of a falciform ligament pedicle flap to decrease pancreatic fistula after distal pancreatectomy. Pancreas 2011; 40: 595-9.

4. Iannitti DA, Coburn NG, Somberg J, Ryder BA, Monchik J, Cioffi WG. Use of the round ligament of the liver to decrease pancreatic fistulas: a novel technique. J Am Coll Surg 2006; 203: 857-64. 
5. Allart K, Prevot F, Rebibo L, Regimbeau JM, Laparoscopic repair of perforated duodenal ulcer, another utilization of round ligament flap (with video). Videosurgery Miniinv 2018 (in press).

6. Park AE, Hoogerboord CM, Sutton E. Use of the falciform ligament flap for closure of the esophageal hiatus in giant paraesophageal hernia. J Gastrointest Surg 2012;16: 1417-21.

7. Dokmak S, Aussilhou B, Ragot E, Tantardini C, Cauchy F, Ponsot P, Belghiti J, Sauvanet A, Soubrane O. Reconstruction of Bile Duct Injury and Defect with the Round Ligament. J Gastrointest Surg. 2017; $21:$ 1540-1543.

8. Ying DJ, Ho GT, Cai JX. Anatomic bases of the vascularized hepatic teres ligament flap. Surg Radiol Anat. 1997; 19: 293-4.

Figure 1-7

Tête: cephalad

Droite: right

Avant: anterior

Fig 8-9

Tête: cephalad

Gauche: left

Avant: anterior 


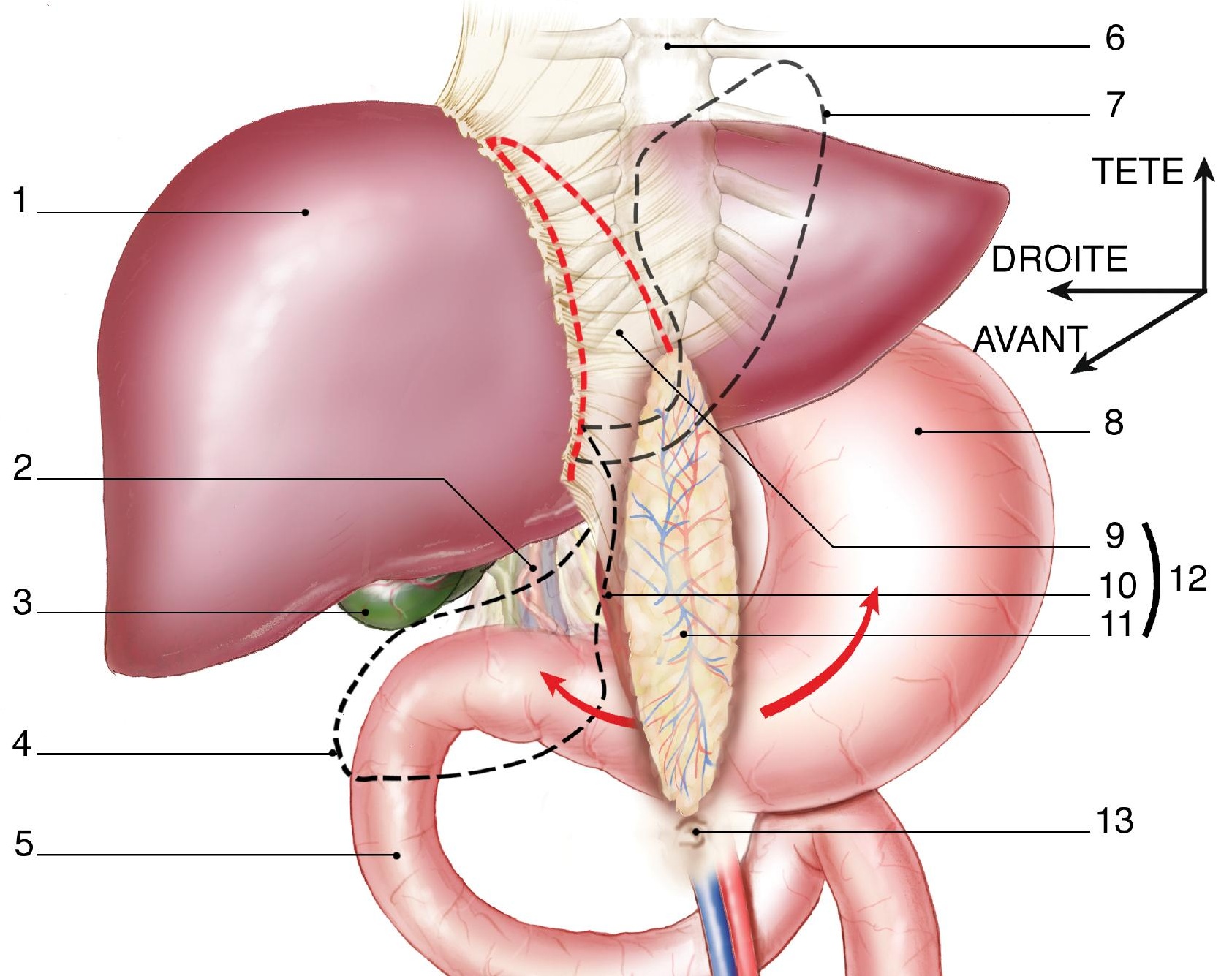




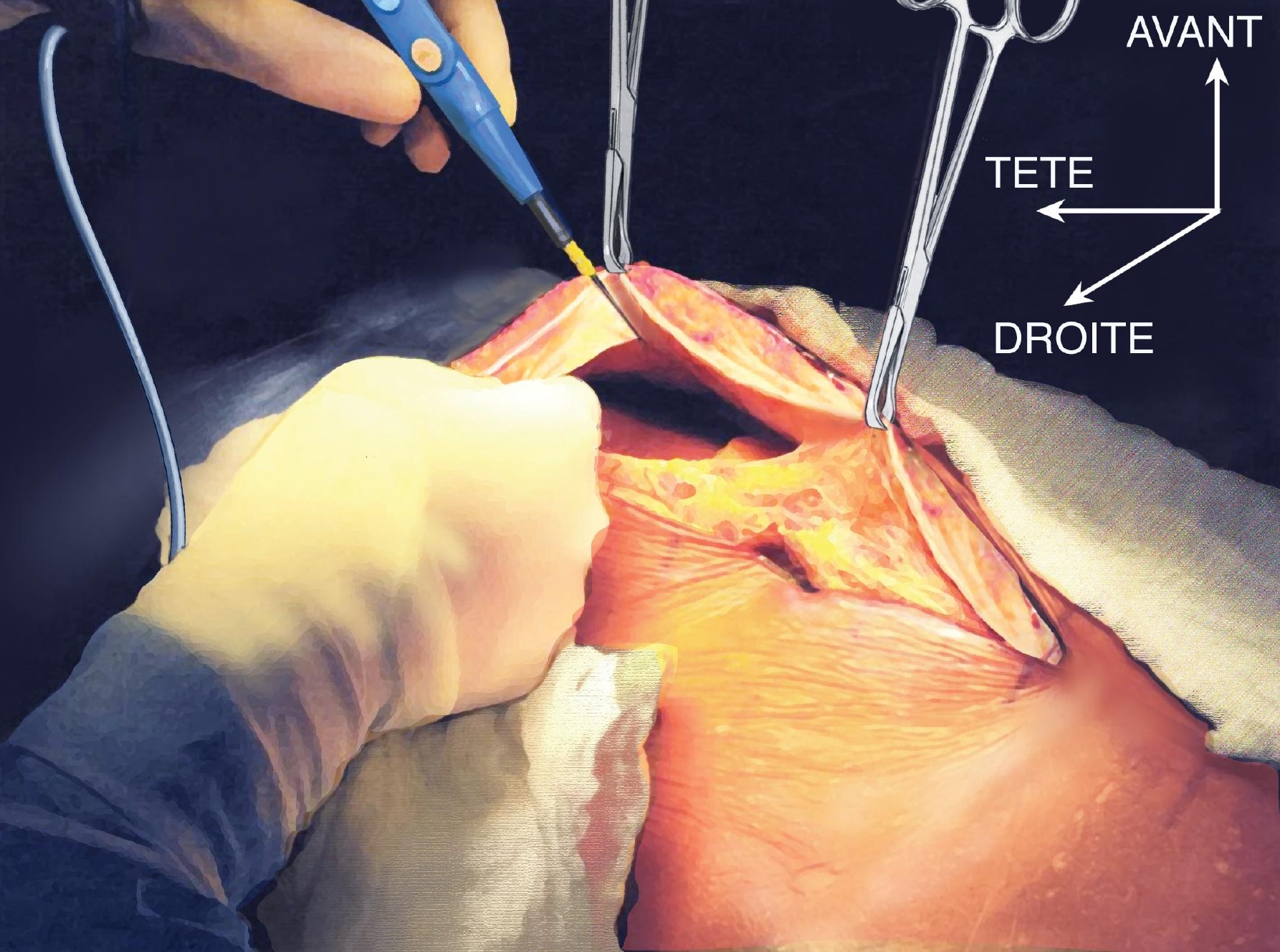




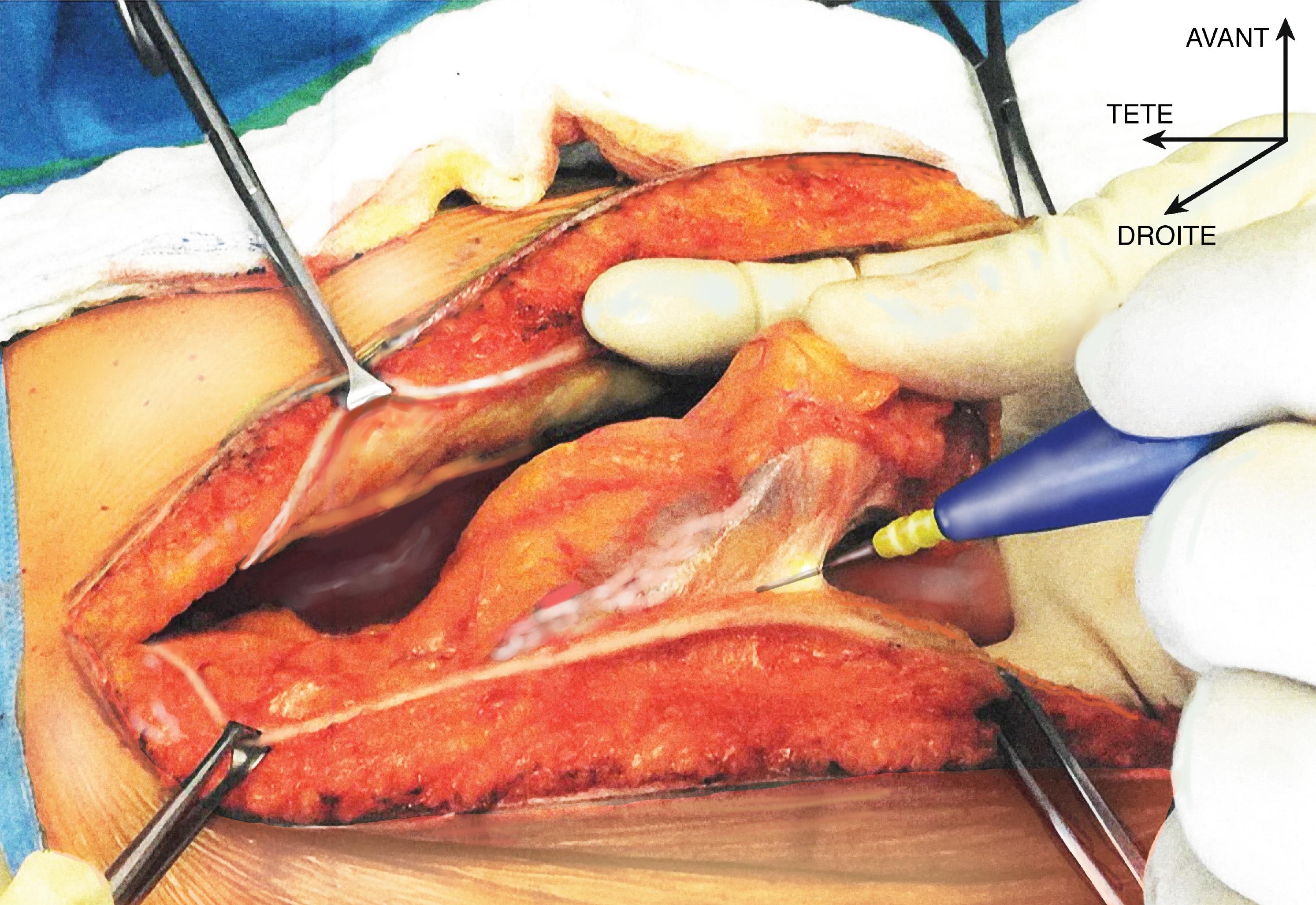




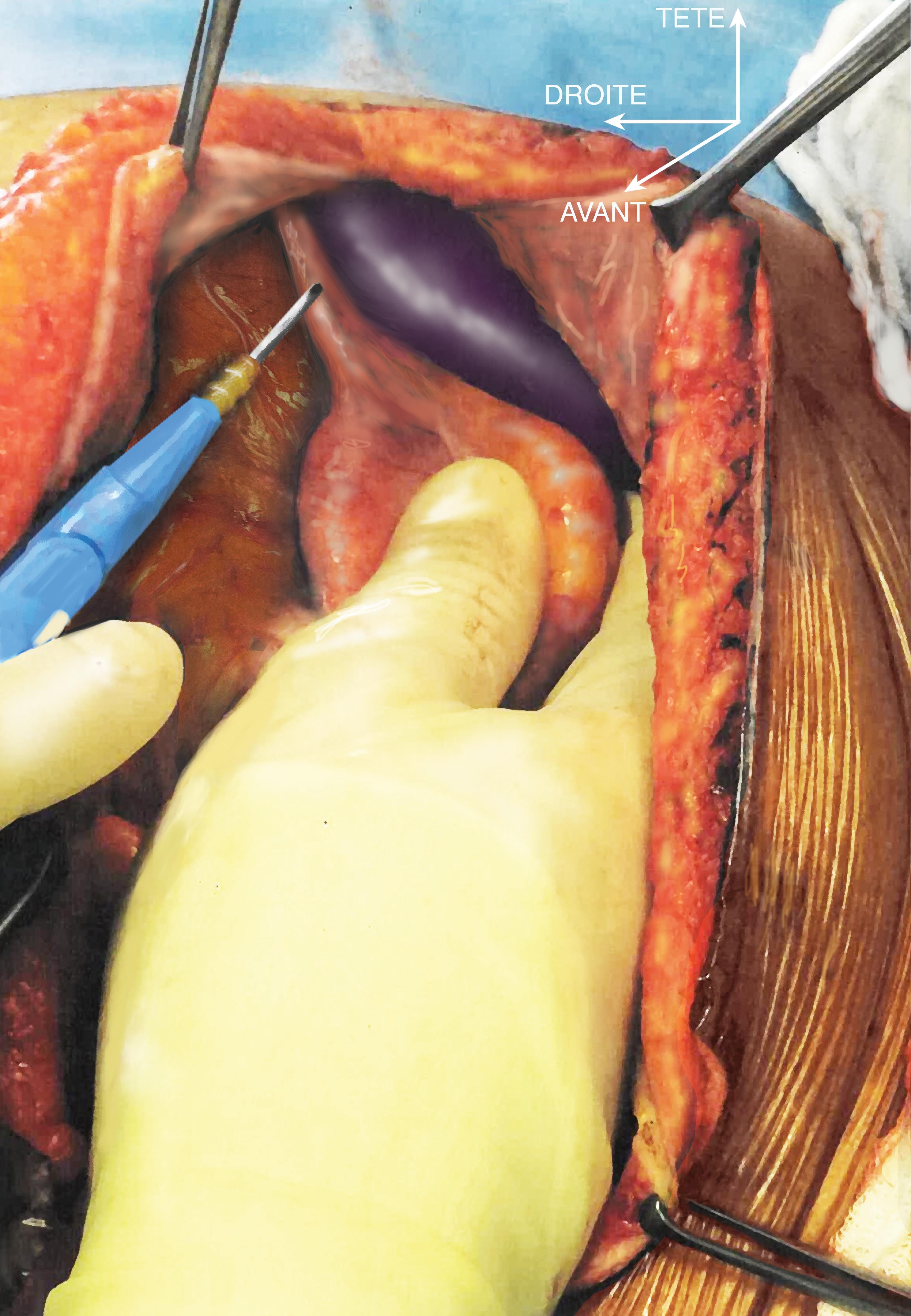





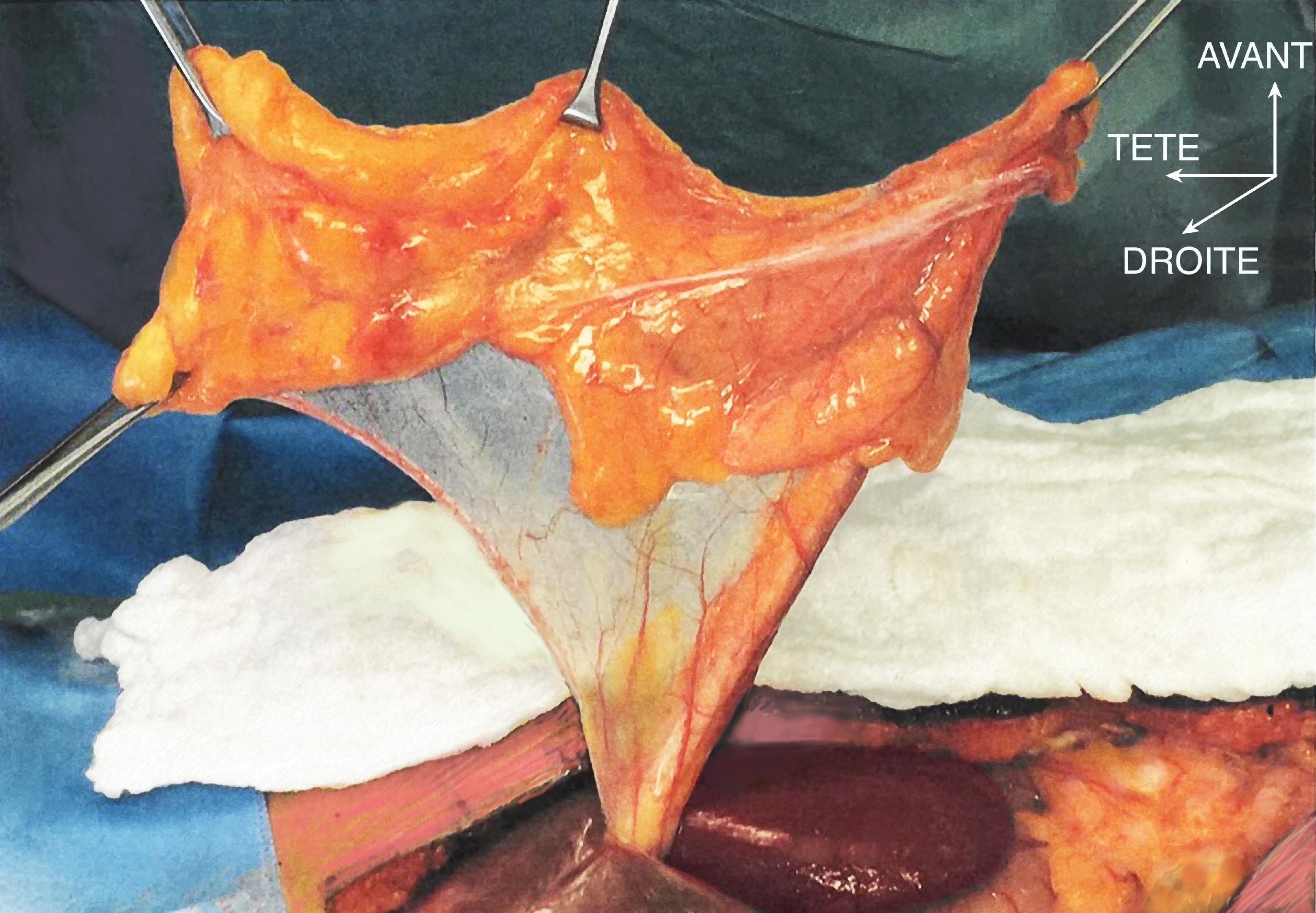




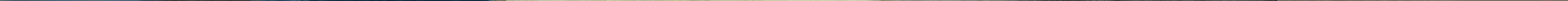




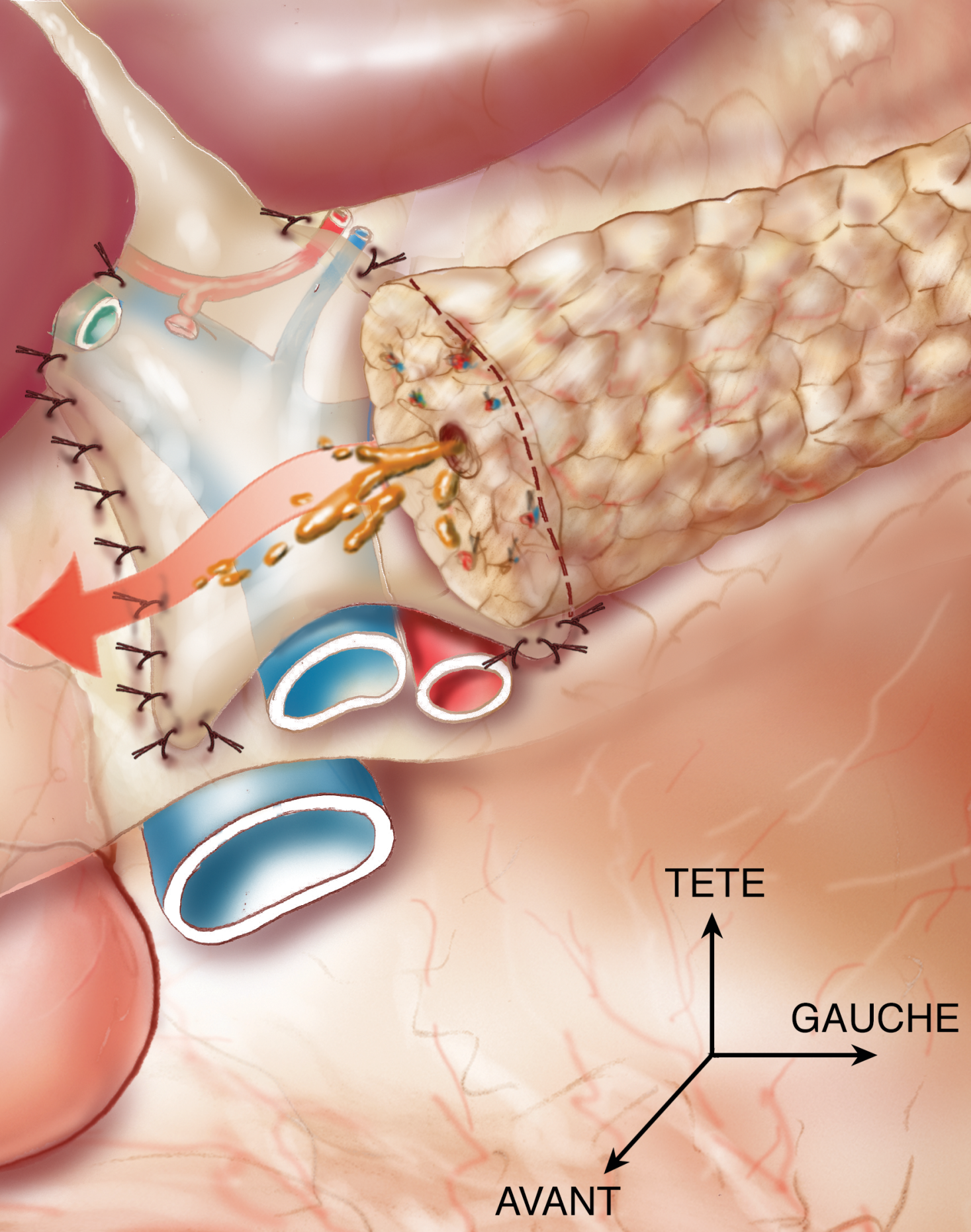


